International Journal of

Health, Medicine and

Nursing Practice

(IJHMNP)

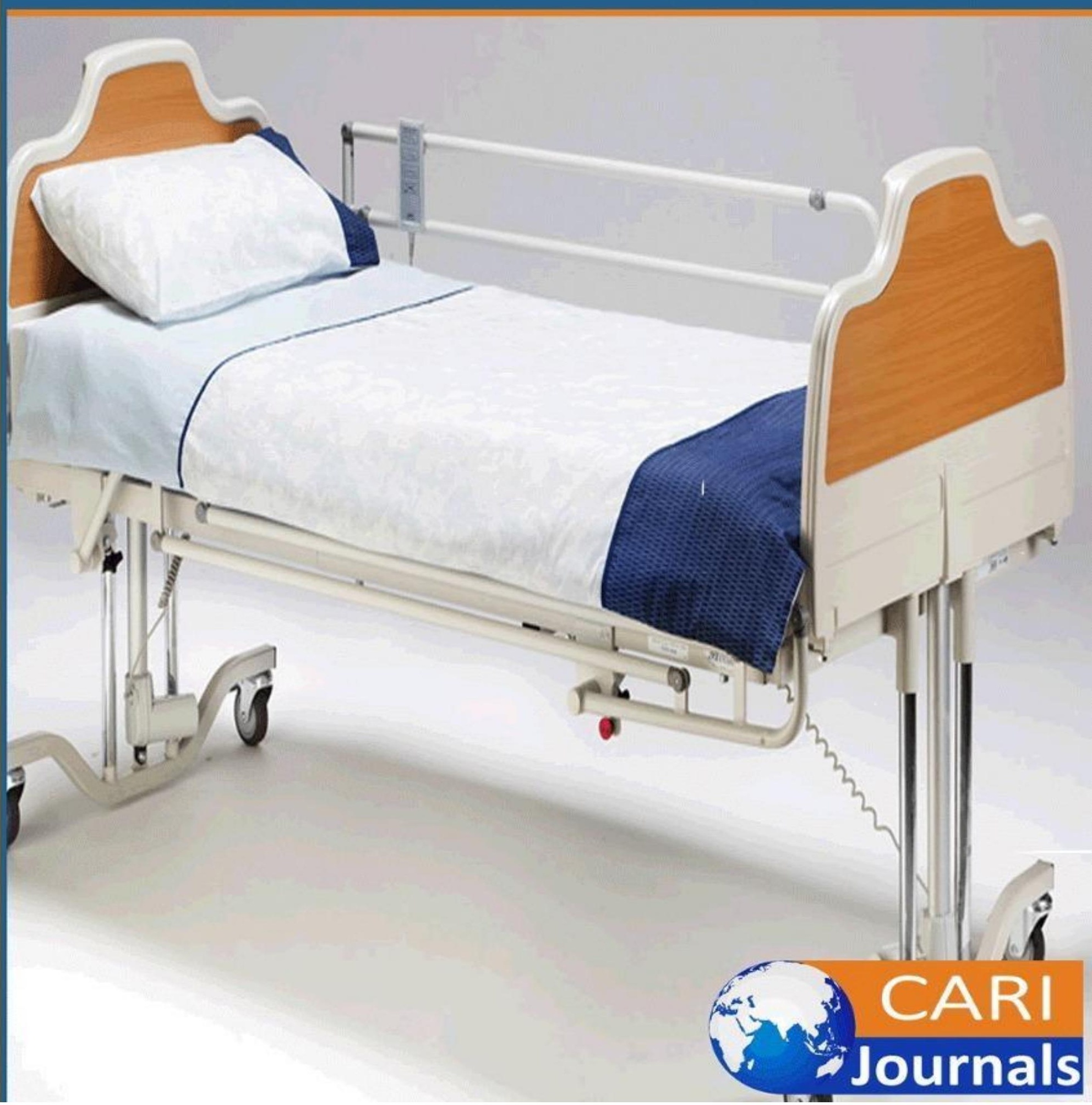




\title{
COLLEGE CONVERSION INTO QUARANTINE CENTER: STUDENTS' PERCEPTION ON COVID-19 MITIGATION MEASURES AT KENYA MEDICAL TRAINING COLLEGE MOMBASA
}

\author{
${ }^{1}$ Winnie Barawa, \\ Kenya Medical Training College (KMTC) \\ Corresponding Authors Email: wbarawa@kmtc.ac.ke \\ ${ }^{2}$ Dr. Marsellah Ogendo \\ Kenya Medical Training College (KMTC) \\ Corresponding Authors Email:mogendo@kmtc.ac.ke \\ ${ }^{3}$ Rhoda Nchogu \\ Kenya Medical Training College (KMTC) \\ Corresponding Authors Email: wbarawa@kmtc.ac.ke \\ ${ }^{4}$ Rachael Mwende, ${ }^{5}$ Caroline Mramba, ${ }^{6}$ Dominic Mutonga, ${ }^{7}$ Dorcas Ngechu, ${ }^{8}$ C.M. Garama, \\ ${ }^{9}$ Jeniffer Mwema ${ }^{10}$ Rita Miriti, ${ }^{11}$ Japheth Ogada Affiliation: \\ ${ }^{[4-11]}$ Kenya Medical Training College (KMTC)
}

\begin{abstract}
Purpose: The aim of the study was to determine the perception of students towards COVID- 19 mitigation measures that were to be implemented by the institution before and after resumption of studies.

Methodology: The study was done at KMTC-Mombasa using descriptive cross-sectional design. Participants (Students) were selected using multi stage sampling and sample size determination was done using Fischers statistical formula at a confidence level of ( $p=95 \%), n=253$. Data was obtained using a structured questionnaire through online surveys and focused group discussions via online platform. Data analysis was done using SPSS and excel then results were presented using tables and narrations.
\end{abstract}

Results: $60.5 \%$ (153) of respondents recommended fumigation of campus facilities especially hostels and classrooms while $11.5 \%$ (29) recommended physical distancing measures before reopening. $41.5 \%$ (105) of respondents suggested the college should provide masks, sanitization points and adequate hand washing facilities after reopening while $19.4 \%$ (49) suggested there should be physical distance indicators in classrooms. The respondents preferred the implementation of preventive measures before resumption $(\mathrm{p}=0.047)$.

Unique contribution to theory, practice and policy: During pandemic, students are keen on infection prevention and strategies put in place by institution management. Fumigation of college facilities, provision of masks, sanitizers and hand washing points were identified as key measures 
to be implemented for the safety of the students. After students have resumed they should be enlightened on COVID-19 through multiple communication channels. COVID-19 Response Committee comprising of college staff and student representatives should be established.

Key words: COVID-19, Kenya Medical Training College, Measures, Mombasa, Perception, Quarantine Center, Students

\section{INTRODUCTION}

The corona virus disease of 2019 (COVID-19) was first declared by the World Health Organization (WHO) as a world health emergency in January 2020 (Jackson, Weiss, Schwarzenberg and Nelson, 2020). Since the declaration, it continued to spread across the world rapidly, thereby affecting individuals socially, economically and also psychologically. Kenya confirmed its maiden case of COVID 19 on $13^{\text {th }}$ March 2020, after which the cases have continued to increase, such that as at $27^{\text {th }}$ July 2020 , Kenya had a total number of 17,975 confirmed cases of COVID-19 (Highlights, 2020). This led to the government of Kenya to come up with several measures to curb the spread of Covid-19 across the country. As part of containment measures the WHO on $29^{\text {th }}$ February introduced quarantine as a control measure which was then adopted by the Government of Kenya in which selected learning institutions and hotels were temporarily converted into COVID-19 quarantine centers. Kenya Medical Training College Mombasa was one of the learning institutions converted into COVID-19 quarantine center where the study was conducted.

Measures available to public health authorities around the world to control COVID-19 pandemic include encouraging citizens to wear masks in public, canceling public events, closing schools, screening for illness, quarantining contacts, isolating cases and enforcing compliance (WHO, 2020). Moreover, Nanyingi (2020) stated that school closure has been effective in enhancing community-level social distancing hence reducing the peak incidence of infections. However, Bender (2020) argues that readily available information and facts about COVID-19 will help diminish students' fear and anxieties around the disease and support their ability to cope with any secondary impacts in their lives.

In a presentation by Kenya National Union of Teachers (2020) to the National Emergency Response Committee on Coronavirus about reopening of schools, colleges and universities, recommended safety measures for consideration before reopening of learning institutions. These included infrastructural development and provision of enough facilities in schools to allow for social distancing, adequate water and water containers in all learning institutions, standardized hand sanitizers, fumigation of learning institutions, protective gear and masks for all teachers and learners. Eventually, when these suggested interventions would be implemented, they would have a substantial impact in limiting the community transmission of COVID-19, thus reducing the potential of human to human transmission (Nanyingi, 2020).

The framework for reopening schools provides that learning institutions should only reopen when students' safety is assured and institutional measures to prevent spread of COVID 19 have been adequately implemented. However, the perception of students as key stakeholders towards safety 
measures taken for learning facilities that were converted into quarantine centers were not considered. The Ministry of Health $(\mathrm{MoH})$ and its stakeholders projected that there could be an increase in cases of COVID-19 in the country, thus had to convert the already identified government institutions into quarantine centers since students were at home creating availability of the amenities for use by the clients.

\section{Problem statement}

There is reported evidence of psychological trauma among students following the COVID-19 pandemic (Yanping et, al. 2020). Since students are key stakeholders in learning institutions their concerns have to be addressed as a good management practice. Having their good will minimizes resistance to resumption of learning.

The idea of quarantine is a new concept in Kenya, several studies has focused on perception of students in relation to either learning or the learning environment. Many students may be fearful especially where college infrastructure has been utilized as quarantine center. Several clients who had been quarantined at KMTC tested COVID-19 positive. Very few studies have examined the perception of students on mitigation measures in learning institution during and after pandemic. This study intends to bridge the gap that seems to exist.

\section{METHODOLOGY}

The study was done at KMTC-Mombasa using descriptive cross-sectional design. Participants (Students) were selected using multi stage sampling. $\mathrm{N}=850, \mathrm{n}=264$, sampling determination was done using Fischer statistical formula $(\mathrm{p}=95 \%)$. Total participants turn up was $253(n=253)$. A structured questionnaire was administered through online surveys and focused group discussions conducted via KENET platform which is an educational platform used video- conferencing. Data analysis was done using SPSS (Statistical Package for Social Science) version 26.0 and excel. Presentation was by use of tables, bivariate analysis and narrations.

\section{RESULTS}


Vol.2, Issue No.2, pp $21-29,2020$

\section{Demographics of respondents}

Table 1: Distribution of Respondents by Age, Gender, Department and Year of study

\begin{tabular}{llcc}
\hline Demographics & Category & Frequency(n=253) & $\begin{array}{l}\text { Percentage } \\
(\%)\end{array}$ \\
\hline Age (Years) & $18-20$ & 61 & 24.1 \\
& $21-24$ & 114 & 45.1 \\
& $25-29$ & 55 & 21.7 \\
& 30 and above & 23 & 9.1 \\
\hline Gender & Male & 101 & 39.9 \\
& Female & 152 & 60.1 \\
\hline Department & Clinical Medicine & 57 & 22.5 \\
& Nursing & 107 & 42.3 \\
& Pharmacy & 41 & 16.2 \\
& Health Records & 21 & 8.3 \\
& Occupational Therapy & 11 & 4.3 \\
& Medical Imaging Science & 16 & 6.3 \\
\hline Year of study & $1^{\text {st }}$ year & 80 & 31.6 \\
& $2^{\text {nd }}$ year & 79 & 31.2 \\
& $3^{\text {rd }}$ year & 78 & 30.8 \\
& $4^{\text {th }}$ year & 16 & 6.3 \\
\hline
\end{tabular}

Table 1 shows 45\% (114) of students are within the age group of 21-24 years while 9.1\% (23) are aged above 30 years. Majority of KMTC students are admitted immediately after secondary school education and tend to belong to 16-25 years.

Gender was defined as biological characteristic of being either male or female. $60.1 \%$ (152) of the respondents were female. This is a true representation of total gender distribution in KMTC Mombasa where female are $60.1 \%$ (504).

Department was defined as the course in which the student is enrolled. The findings reveal that majority of the students are in the Nursing department $42 \%$ (107). This is because nursing department has two intakes per year unlike other departments that have one intake and it extends to three and a half years while the other courses range between two and three years' academic years.

Year of study was defined as the academic year of the student as stipulated by KMTC curriculum. $6.3 \%$ (16) of the respondents were from fourth year of study and from nursing department which offers three and half years. Generally, the students are evenly distributed in year one, two and three ranging from 30 to 31 and year four is less because the only program is nursing 


\section{COLLEGE MITIGATION MEASURES TO PREVENT SPREAD OF COVID-19}

Measures referred to actions that the college would take to prepare for the resumption of college activities (before and after) while mitigation referred to specific preventive measures to minimize spread of COVID-19. This would help the college get student perception as key stakeholders hence prepare adequately and establish safe systems for their resumption. To address the above objective, participants were asked through structured questionnaire to highlight measures the college should take to maintain safety and prevent spread of COVID-19 before and after return to college. Results were as follows:

Table 2: Measures to be taken by the college before students resume college.

\begin{tabular}{|c|c|c|c|}
\hline & & Frequency $(n=253)$ & $\begin{array}{c}\text { Percentage } \\
(\%)\end{array}$ \\
\hline \multirow{9}{*}{$\begin{array}{l}\text { Measures to be } \\
\text { taken before } \\
\text { resumption of } \\
\text { school }\end{array}$} & Put physical distance indicators & 29 & 11.5 \\
\hline & Testing of students and staff & 9 & 3.6 \\
\hline & Restructure clinical rotation & 2 & 0.8 \\
\hline & $\begin{array}{l}\text { Communication and education on } \\
\text { COVID- } 19\end{array}$ & 10 & 4 \\
\hline & Fumigation & 153 & 60.5 \\
\hline & Availability of PPE & 21 & 8.3 \\
\hline & Discharge Quarantine Clients & 10 & 4 \\
\hline & Implement WHO/MOH guidelines & 19 & 7.5 \\
\hline & Total & 253 & 100 \\
\hline
\end{tabular}

$60.5 \%$ (153) of the respondents recommended for fumigation of campus facilities especially hostels and classroom while $0.8 \%$ (2) recommended that the college should restructure the clinical rotations putting in consideration issues such as student medical conditions and health issues. Our findings agreed with recommendations made by Kenya National Union of Teachers (KNUT), Universities Academic Staff Union (UASU) and Kenya Human Rights Commission (KHRC) to the National Emergency Response Committee (NERC) on coronavirus that stated schools should implement preventive measures including: setting hand washing facilities, fumigation, sanitations centers, mass testing of students and setting up of facilities to handle any cases that may arise. The report also noted other additional measures including regular risk assessment of lecturers and staff in the college, restructuring of learning hours so that students are thought in phases where Phase 1 are taught in the morning while phase 2 are taught in the afternoon to ease congestion and maintain social distance since there is inadequate resources for classrooms expansion. 
Vol.2, Issue No.2, pp $21-29,2020$

Table 3: Measures before resumption of college (chi-square of safety of classroom and measures)

\begin{tabular}{lcc}
\hline & Value & $\begin{array}{c}\text { Asymptotic Significance } \\
\text { (2-sided) }\end{array}$ \\
\hline Pearson ChiSquare & $14.252^{\mathrm{a}}$ & 0.047 \\
Likelihood Ratio & 14.975 & 0.036 \\
N of Valid Cases & 253 & \\
\hline
\end{tabular}

The respondents felt that measures recommended before resumption if implemented well will make them feel safe in the classroom $(\mathrm{P}=0.047)$. The key role of learning occurs in classroom which presents a compulsory area that students will spend most of their time. E-learning is still a new concept to students hence yet to acquit themselves to this new normal. However, the significance indicates that more measures need to be implemented to improve safety of the classroom such as fumigation and putting of physical distance indicators. During focused group discussion the participants recommended the KMTC management to allocate large lecture halls for lecturing activities to help achieve 1.5-meter physical distance.

Table 4: Measures to be taken by the college after students resume college

\begin{tabular}{|c|c|c|c|}
\hline & & $\begin{array}{c}\text { Frequency } \\
\mathbf{n}=253\end{array}$ & $\begin{array}{c}\text { Percentage } \\
\%\end{array}$ \\
\hline \multirow{12}{*}{$\begin{array}{l}\text { Measures to taken } \\
\text { after resumption } \\
\text { of college }\end{array}$} & Regular testing of students & 11 & 4.3 \\
\hline & Improve college infrastructure & 16 & 6.3 \\
\hline & Masks, sanitization, hand washing & 105 & 41.5 \\
\hline & Restrict movement & 12 & 4.7 \\
\hline & No clinical placement & 5 & 2 \\
\hline & Fumigation of hostel and classrooms & 25 & 9.9 \\
\hline & Screening at the Entrance & 6 & 2.4 \\
\hline & Establish Isolation facility in the college & 1 & 0.4 \\
\hline & $\begin{array}{l}\text { Marking of physical distance in hostel } \\
\text { and classrooms }\end{array}$ & 49 & 19.4 \\
\hline & $\begin{array}{l}\text { Health Education on COVID } 19 \text { to all } \\
\text { students }\end{array}$ & 21 & 8.3 \\
\hline & $\begin{array}{l}\text { Care of students with pre-existing } \\
\text { conditions }\end{array}$ & 2 & 0.8 \\
\hline & Total & 253 & 100 \\
\hline
\end{tabular}


$41.5 \%$ (105) of the respondents suggested the college should provide masks, sanitization points and adequate hand washing facilities while $0.4 \%$ (1) recommended that the college should establish an isolation facility to host students who fall ill due to COVID-19 while within college. According to the proposed plan by the Ministry of Education (M.O.E) under Kenya Early Education there was an emphasis on establishing WASH facilities and conducting vibrant health education for the students on COVID-19 upon resumption of school activities. They also highlighted provision of counseling and debriefing services to students and staff in schools that were used as quarantine centers to enable them recover from COVID-19 fears.

Table 5: chi-square test between safety and mitigation measures after resumption

\begin{tabular}{lcc}
\hline & Value & $\begin{array}{c}\text { Asymptotic } \\
\text { Significance } \\
\text { (2sided) }\end{array}$ \\
\hline Pearson Chi-Square & $19.908^{\mathrm{a}}$ & 0.03 \\
Likelihood Ratio & 20.471 & 0.025 \\
N of Valid Cases & 253 & \\
\hline
\end{tabular}

There was a notable significance $(\mathrm{p}=0.030)$ between the feeling of safety and the mitigation measures implemented once the college resumes. The students however didn't feel safe before resumption of college $(\mathrm{p}=0.143)$. This implied that once the proposed measures have successfully been implemented, their level of confidence to resume school increases. It also insinuated that before resumption the college is still under quarantine and measures may not be effective enough to protect them from the COVID-19 infection.

\section{DISCUSSION}

The World Health Organization declared COVID 19 as a Public Health Emergency of International Concern leading to closure of learning institutions and social gatherings. Several public health measures were proposed to prevent and control transmission of COVID-19; these included case identification, contacts tracing and case isolation, environmental disinfection and use of personal protective equipment (WHO, 2020). The implementation of case isolation led to conversion of several learning institutions in Kenya into COVID-19 quarantine centers to focus on triaging and sorting of suspected contact clients. Kenya Medical Training College were among the quarantine centers. Several reports agreed with our study. A report by UNICEF (2020), stated that school administrators, teachers and staff should apply the following basic principles: non reporting to school of staff and learners with other medical conditions, enforcing of hand washing techniques, provision of clean water and waste management facilities, promotion of social and physical distance, proper health education messaging on COVID-19, establish systems that will handle sick 
students from COVID-19 and plan a continuity of learning methods such as E-learning, home study, radio and weekly remote follow up.

According to Afolabi O. et al, (2016) the most important strategy to undertake to prevent infection is to frequently wash hands. They concluded that there is relationship between hand hygiene and illness rate. The study further suggested that both hand washing and the use of hand sanitizers had positive effect on the wellness of medical students.

Upon reopening of schools, the Daily Nation briefing (02 July 2020) through the Ministry of Education reported that all learning institutions in Kenya should emphasize on dangers of the deadly disease, teachers to adopt online learning, infrastructure to be fumigated regularly, adequate funding be allocated for extra school infrastructures, a case that support our findings. UNESCO series (2020) on COVID-19 and reopening of schools encourages schools to maintain constant communication with key stakeholders on issues of dates and conditions of reopening based on the principles of communicate, consult and coordinate. They advise to use multiple channel for wide reach i.e. radio, television, internet and if possible community meetings.

However previous researches do not address the influence of perception on safety and demographics on the mitigation measures taken to prevent spread of COVID 19 in learning facilities.

The study had limitations on accessing adequate literature review on facilities that had been converted to quarantine centers. Prior public data based their preventive measures only from the government guidelines and had less involvement of the end users i.e. students.

In conclusion, there is clear need to implement preventive measures before and after resumption of the college activities to optimize on controlling the spread of COVID 19.

\section{RECOMMENDATIONS}

1. College Management should implement proposed measures before resumption of learning activities.

2. After students have resumed they should be enlightened on COVID-19 through multiple communication channels.

3. COVID-19 Response Committee comprising of college staff and student representatives should be established.

\section{REFERENCES}

Afolabi OO, Adewumi EO, Medavarapu S 2016). A Study to ascertain the Practice of Hand Hygiene among Medical Students in Commonwealth of Dominica. Doi:

$10.21767 / 19895216.1000165$

Bender L. (2020). Key messages and actions for COVID-19 prevention and control in schools. UNICEF: New York.

Highlights, (2020) COVID- 19 outbreak in Kenya. July,1-16 
IIEP-UNESCO. 2010. Guidebook for planning education in emergencies and reconstruction, 297-327. Paris: iiep-unesco.

Jackson, J. K.,Weiss, M. A., Schwarzenberg A. B. and Nelson R. M. (2020). Global Economic Effects of COVID-19. Congressional Research Service. Retrieved $7^{\text {th }}$ July 2020, from: https://crsreports.congress.gov..

Kenya Human Rights Commission.(2020) Https://www.khrc.or.ke/publications/215multiagency-report-on-effects-of-coronavirus-covid-19-pandemic-on-educationmitigationmeasures-analysis-and-recommendations-on-reopening-of-schoolscollegesuniversities/file.html

MOE, (2020). Kenya Basic education Covid-19 Emergency Response Plan. Retrieved $7^{\text {th }}$ July 2020, from: https://www.education.go.ke/images/Kenya_basic_Education_COVID-

19_Emergency_Response_Plan-compressed.pdf

Mureithi, F. (2020). Covid-19: schools urged to improve safety measures before reopening. Daily nation.

Nanyingi M. (2020). What Kenya must look out for before easing COVID-19 restrictions.

Retrieved $8^{\text {th }}$ July 2020, from: https://theconversation.com/what-kenya-must-look-outforbefore-easing-covid-19-restrictions-139677

Kenya National Union of Teachers, Universities Academic Staff Union and Kenya Human Rights Commission. (2020). Effects of coronavirus pandemic on education - mitigation measures, analysis and recommendations on reopening of schools, colleges \& universities. Https://www.khrc.or.ke/publications/215-multi-agency-report-on-effectsofcoronavirus-covid-19-pandemic-on-education-mitigation-measures-analysisandrecommendations-on-reopening-of-schools-colleges-universities/file.html

UNESCO international institute for higher education in latin america and the caribbean (iesalc). (2020). Covid-19 and higher education: today and tomorrow: impact analysis, policy responses and recommendations. Unesco.

UNICEF (2020). Key messages and actions for covid-19 prevention and control in schools. https://www.who.int/docs/default-source/coronaviruse/key-messages-and-actions-forcovid-19prevention-and-control-in-schools-march-2020.pdf?sfvrsn=baf81d52_

Yanping B., Yankun S.,Shiqiu M.,Jie S., Lin L.,(2020). 2019-nCoV epidemic: address mental health care to empower society Published: February 07, 2020DOI:https://doi.org/10.1016/S0140-6736(20)30309-3 